\title{
14. QUATERNARY AND PLIOCENE TURBIDITES IN THE BAHAMAS, LEG 101, SITES 628, 632, AND 6351
}

\author{
Gerhard Kuhn² and Dieter Meischner ${ }^{3}$
}

\begin{abstract}
Textural and compositional differences were found between gravity-flow sheets in an open-ocean environment on the northern slope of Little Bahama Bank (Site 628, Pliocene turbidite sequence) and in a closed-basin depositional setting (Site 632, Quaternary turbidite sequence). Mud-supported debris-flow sheets were cored at Site 628. Average mean grain size of the turbidite samples was lower, mud content was higher, and sorting was poorer than in comparable samples from Site 632. This reflects the deposition of proximal, low-energy turbidity currents and debris flows on a base-ofslope carbonate apron. No mud-supported debris-flow sheets were deposited in the investigated sediment sequence of Hole 632A. Many larger turbidity currents from around the margins of Exuma Sound may have reached this central basin setting, depositing sediments that had been transported over longer distances. Planktonic components dominate in the grain-sized fraction $(500-1000 \mu \mathrm{m})$ of turbidite samples from Hole $628 \mathrm{~A}$, while platform detritus is rare. We interpreted this as resulting from the erosion and reworking of a large area of open-ocean slope sediments by gravity flows. In contrast, large amounts of benthic and platform components were found in the turbidite samples of Hole 632A. This may be explained by the fact that the slopes of the enclosed Exuma Sound are steep, and turbidity currents bypassed much of these slopes through pronounced channels, delivering more shallow-water detritus to the deep basin. Erosion of slope sediments, a possible source area of planktonic detritus, is assumed to be low. The small slope area in relation to the larger surrounding platform areas and lower production of planktonic components in the enclosed waters of Exuma Sound may also explain the observed low number of planktonic components at Hole 632A. Turbidite material from both open-ocean and enclosed-basin environments was deposited at Site 635 .
\end{abstract}

\section{INTRODUCTION}

Downslope sediment transportation from carbonate platforms differs fundamentally from downslope transportation in siliciclastic environments with respect to changes in sea level. Unlike siliciclastic slopes, where shelf erosion and high sediment input occur during low sea-level stands, downslope sediment transportation from carbonate slopes seems to reach a maximum during high sea-level stands as a result of high sediment production on the flooded banks (Kier and Pilkey, 1971; Lynts et al., 1973; Crevello and Schlager, 1980; Schlager and Ginsburg, 1981; Mullins, 1983; Boardman and Neumann, 1984; Droxler, 1984). Shanmugam and Moiola (1984) further suggested that most downslope transportation from isolated carbonate platforms can be expected during the initial stage of lowering of sea level, resulting from unstable high sea-level sediment accumulations on the slope combined with a lowered wave base. Droxler and Schlager (1985) showed that a large debris sheet in Exuma Sound follows this pattern, but that turbidites in the upper part of Tongue of the Ocean do not. These turbidites show maximum frequency, thickness, and accumulation rates during the early phase of a high sea-level stand, followed by a gradual decline.

To resolve the relationship between turbidity-current activity and sea-level stands, one must sample a sediment section that has both high sedimentation rates and high frequencies of turbidites to provide a good statistical basis. Droxler and Schlager (1985) found these conditions optimal in the southern part of Tongue of the Ocean (Cul de Sac), where average bulk sedimentation rates of $9 \mathrm{~cm} / 1000 \mathrm{yr}$, average turbidite accumulation rates of $6 \mathrm{~cm} / 1000 \mathrm{yr}$, and average turbidite frequencies of 5/

\footnotetext{
${ }^{1}$ Austin, J. A., Jr., Schlager, W., et al., 1988. Proc. ODP, Sci. Results, 101: College Station, TX (Ocean Drilling Program).

2 Alfred Wegener Institute for Polar and Marine Research, Columbusstrasse, D-2850 Bremerhaven, Federal Republic of Germany.

${ }^{3}$ Institut für Geologie und Paläontologie, Universität Göttingen, Goldschmidtstrasse 3, D-3400 Göttingen, Federal Republic of Germany.
}

1000 yr during high sea-level stands (interglacials) occur. During low sea-level stands (glacials), bulk sedimentation rates were lower by approximately a factor of $5(=2 \mathrm{~cm} / 1000 \mathrm{yr})$, turbidite accumulation rates by a factor of $19(=0.3 \mathrm{~cm} / 1000 \mathrm{yr})$, and turbidite frequencies by a factor of $10(=0.5 / 10,000 \mathrm{yr})$.

All previous studies were conducted on sediment cores with lengths of less than $15 \mathrm{~m}$. Therefore, only a few glacial/interglacial cycles could be investigated. Our investigations were aimed at obtaining information about the influence of sea-level fluctuations related to glacial/interglacial periods on turbidite frequency and turbidite components during the whole Quaternary and Neogene. During Leg 101 we hoped to sample a thick Quaternary to late Tertiary turbidite sequence with high sedimentation rates and high frequency of turbidites to obtain a good resolution of individual phases of sea-level fluctuations.

Turbidite series that accumulated during Quaternary and late Tertiary eustatic sea-level fluctuations were drilled at two sites during Leg 101 (Austin, Schlager, et al., 1986): (1) a Pleistocene series at Hole $632 \mathrm{~A}$, on the basin floor of southeastern Exuma Sound; and (2) a Pliocene series at Hole 628A, north of Little Bahama Bank (Fig. 1). Unfortunately, accumulation rates and turbidite frequencies were low at both sites; therefore, a correlation with sea-level fluctuations would not be statistically viable. Considering this, only long periods of variation and general differences in the composition of the two turbidite series were investigated to obtain information about the environmental setting of an open-ocean slope and an enclosed basin. In addition, turbidite layers at Hole 635A, situated in Northeast Providence Channel, also were sampled and analyzed for a comparative study of different turbiditic environments.

\section{METHODS OF INVESTIGATION}

\section{Estimates of Sediment-Accumulation Rates}

Average sediment-accumulation rates (Fig. 2) for the Pliocene turbidite section of Hole 628A and the Quaternary turbidite section of Hole 632A were determined by shipboard paleontologists during Leg 101 (Austin, Schlager, et al., 1986). 


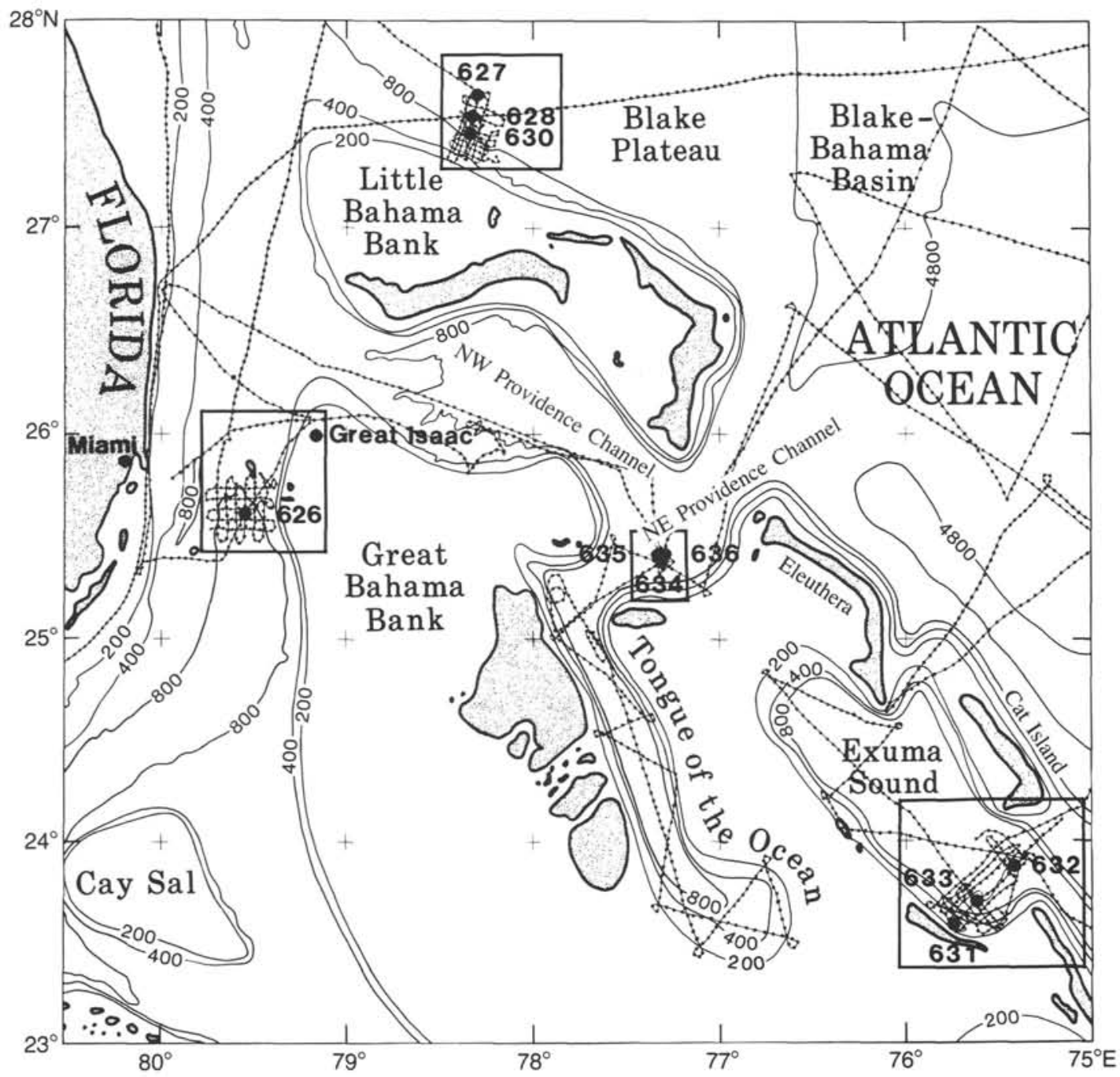

Figure 1. Index map showing Leg 101 drilling sites and geophysical site-survey coverage in the Bahamas. Bathymetric contours are in meters (see synthesis chapter, this volume).

\section{Identification of Turbidite Layers}

Shipboard visual core descriptions were most important for identifying turbidite layers and for distinguishing them from interbedded periplatform ooze or from other kinds of gravity flows. The following criteria were used by shipboard sedimentologists to identify turbidite layers (Austin, Schlager, et al., 1986). These criteria also were used in many other investigations of carbonate turbidites (Bouma, 1962, 1972; Meischner, 1962, 1964; Droxler and Schlager, 1985; Mullins and Cook, 1986).

1. Sharp base, gradational top.

2. Normal graded bedding in layers of sand, rubble, and silt (reversed graded bedding only in two layers).

3. Grainstone- to packstone-textured layers (rudstone texture at the base of some layers) interbedded with a sediment of mudstone to wackestone texture.

4. Numerous shallow-water carbonate grains.

5. Fine-grained layers with a high silt content; often slightly different in color than intercalated muddy sediment.

Within these turbidite layers, the characteristic sequence of sedimentary structures, such as current ripples or parallel lamination described by Bouma (1962) and Meischner $(1962,1964)$, was seldom clearly visible in the unlithified sediments of the freshly cut core halves. Only the graded interval was easy to recognize.

Many layers of floatstone texture contain large, poorly indurated mud clasts in a mud-supported matrix. They have a homogeneous struc- ture and are believed to have been transported predominantly by highdensity, viscous debris flows, not by turbidity currents.

\section{Samples from Turbidite Layers}

At Hole 628A, 16 turbidite layers were sampled from a few meters below the seafloor (mbsf) to 75 mbsf. At Hole 632A, 10 turbidite layers (down to $50 \mathrm{mbsf}$ ) were sampled. From the first core (Core 101-635A-1R) at Hole 635A, four samples were recovered from turbidite layers to compare the depositional environments of the different sites.

Approximately $10 \mathrm{~cm}^{3}$ was collected on board ship from a homogeneous part of a turbidite layer with high sand content near the base. All samples were processed with $2 \% \mathrm{H}_{2} \mathrm{O}_{2}$ solution to disperse them for grain-size analysis. They were then wet sieved through a $63-\mu \mathrm{m}(4 \phi)$ sieve. Sediment fractions coarser than $63 \mu \mathrm{m}$ were dry sieved in $1 \phi$ fractions with an ATM Sonic Sifter. Grain-size distributions of fractions smaller than $63 \mu \mathrm{m}$ were analyzed using a Micromeritics Sedigraph 5000 .

Grain-size distribution of any fraction finer than $63 \mu \mathrm{m}$ was measured twice from each sample to prove the reproducibility of this method. The greatest difference between these two grain-size curves was approximately $5 \%$ of any fraction finer than $63 \mu \mathrm{m}$. Grain-size parameters (median, mean, sorting, skewness, and kurtosis values) were calculated according to Folk and Ward (1957).

Grains of $500-1000-\mu \mathrm{m}(1-0 \phi)$ sand fraction were identified, and the composition of this grain-size fraction was calculated. For each sample sufficient material existed to obtain statistically reliable results. On this basis different samples could be compared. Because the grains of the in- 

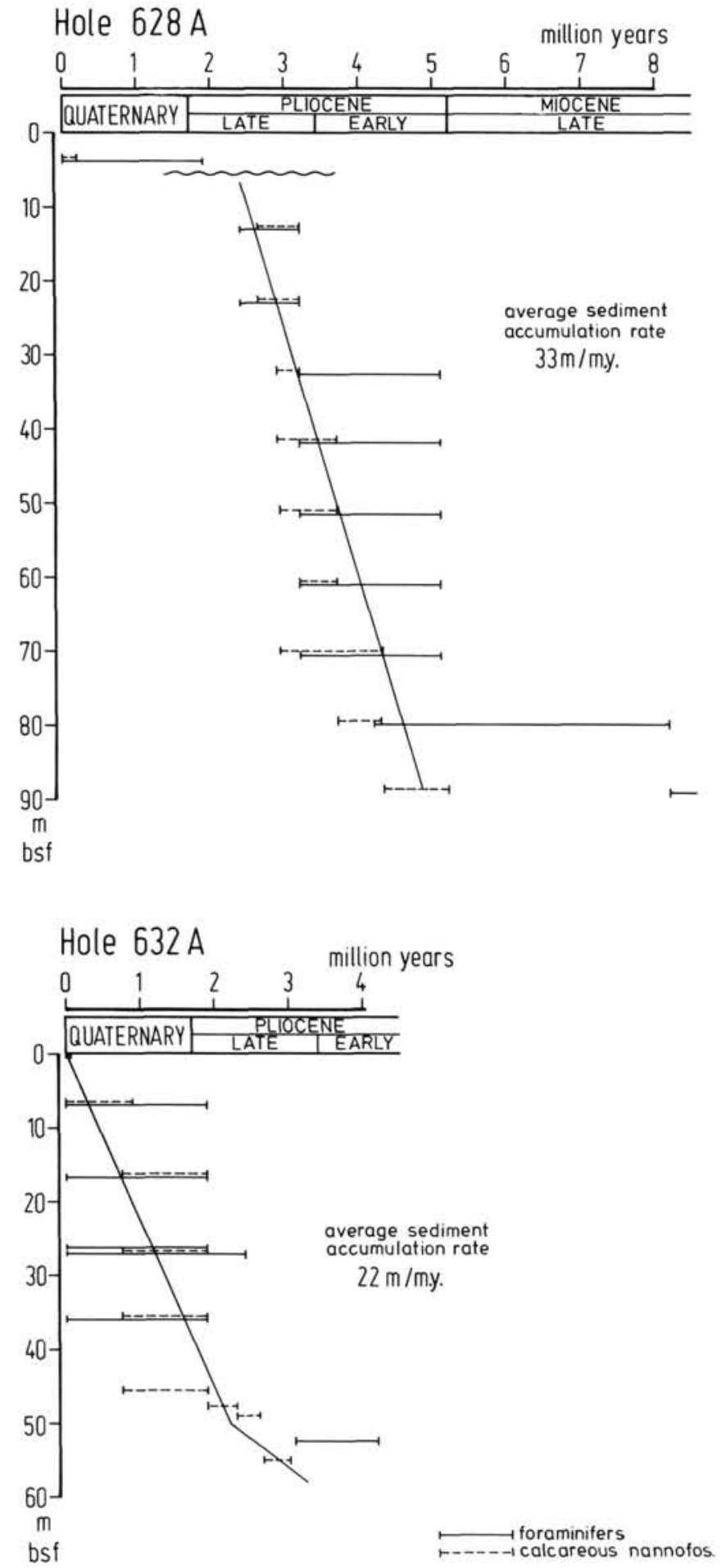

Figure 2. Average sediment-accumulation rates from Holes $628 \mathrm{~A}$ and $632 \mathrm{~A}$, determined by shipboard paleontologists (Austin, Schlager, et al., 1986).

vestigated fraction were large and usually easy to identify, analyses of the composition were quick and reproducible.

Composition of the 500-1000- $\mu \mathrm{m}$ sand fraction was studied for general composition of the turbidite layers, variation of the composition with time, and comparison of turbidites from different environments. By analyzing only a narrow grain-size fraction (500-1000 $\mu \mathrm{m})$, the problem of looking at compositions produced by different hydraulic reactions of grains having different diameters in the turbidity current was avoided.
The following components were identified: (1) planktonic foraminifers: Orbulina spp., other planktonic foraminifers (mainly Globigerinidae, some Globorotaliidae), aggregates of foraminifers (mainly planktonic foraminifers); (2) pteropods: Cuvieridae, Limacinidae; (3) benthic foraminifers: Textulariina, Miliolidae, Soritidae, Homotrema rubrum, other Rotaliina; (4) macrobenthos: gastropods, bivalves, red algae, $\mathrm{Ha}$ limeda spp.; (5) other skeletal fragments and grains (mainly skeletal fragments of benthic organisms: echinoids, bryozoans, corals, hydrozoans, ostracodes, worm tubes, ooids and undetermined polished grains); and (6) aggregates: lithified clasts or cemented grains.

An average of 420 grains per sample (grain-size fraction of 500$1000 \mu \mathrm{m}$ ) were counted. The lowest number of grains per sample counted was 201 , which was still high enough to get reliable results for a comparative study of different samples.

Sample 101-632A-3H-6, 9-12 cm, was counted twice to check the reliability of the calculated composition. The results are plotted in a chart following van der Plas and Tobi (1965), within the values of standard deviation for different values of total number of counted grains and real content of a component (in percentages). This demonstrates the statistical validity of our results.

\section{RESULTS}

\section{Turbidite Sequences}

Quaternary and Neogene turbidite series were examined along slope transects north of Little Bahama Bank and in the southeastern part of Exuma Sound. Three sites were drilled on the northern slope of Little Bahama Bank (Fig. 1). Site 627 (water depth of $1028 \mathrm{~m}$ ) was situated at the downslope end of the Little Bahama transect. At Hole 627B, Quaternary and Neogene sediments were deposited at a relatively low average accumulation rate of 14 to $15 \mathrm{~m} / \mathrm{m}$.y. This section was composed of periplatform ooze with thin turbidites and some debris-flow sheets and slumps. Site 628 (water depth of $966 \mathrm{~m}$ ) was located approximately $11 \mathrm{~km}$ upslope from Site 627. Mullins et al. (1984) investigated the recent sediment cover of this area and suggested that this region is the proximal part of a debris apron having sediments characterized by more abundant, thick, coarse-grained turbidites and by mud-supported debris flows. The Pliocene sediments from Hole $628 \mathrm{~A}$ generally supported this view. Site 630 (water depth of $807 \mathrm{~m}$ ) marked the upslope end of the Little Bahama Bank transect. This site was situated on an interfluve between gullies. Therefore, we drilled into nearly turbidite free periplatform ooze of Quaternary and Pliocene age (Austin, Schlager, et al., 1986).

A similar sediment section was found at Site 631 (water depth of $1081 \mathrm{~m}$ ) in the southeastern part of Exuma Sound, which, like Site 630 , was located on the upper gullied slope. At Hole $631 \mathrm{~A}$, we drilled into a turbidite-free periplatform-ooze series having high accumulation rates. Site 633 (water depth of $1681 \mathrm{~m}$ ) was situated at the toe-of-slope environment of Exuma Sound, analogous to Site 628 north of Little Bahama Bank. Although a high sediment-accumulation rate characterized the sediment sequence at Hole $633 \mathrm{~A}$, turbidites were unusually few, thin, and fine grained. At Site 632 (water depth of $1996 \mathrm{~m}$ ) in the basin floor of southeast Exuma Sound, we recovered a sediment sequence having numerous turbidites (Austin, Schlager, et al., 1986). The turbidites of Hole 635A (water depth of $3459 \mathrm{~m}$ ) in Northeast Providence Channel also were deposited in a basinfloor environment.

\section{Frequency of Turbidites}

\section{Hole 628A}

At Hole 628A, we drilled into a Pliocene turbidite sequence up to $35 \mathrm{~m}$ thick (Cores 101-628A-2H through 101-628A-5H) just below a thin, late Quaternary sediment cover (Core 101628A-1H). Cores 101-628A-6H and 101-628A-7H contain almost no turbidite layers. At a depth of 65 to $75 \mathrm{mbsf}$, we cored another turbidite series. Fine-grained carbonate sediments (peri- 
platform ooze) with slump structures and thin turbidite layers were recovered from 75 to 111 mbsf (upper Miocene to lower Pliocene).

The average sediment-accumulation rate (Fig. 2) through the Pliocene interval was $33 \mathrm{~m} / \mathrm{m}$.y. (Austin, Schlager, et al., 1986). The upper turbidite series consists of 44 turbidite layers and five debris-flow sheets intercalated with calcareous periplatform ooze (Fig. 3). We calculated the following average values: bulk-sedimentation rate of $3.3 \mathrm{~cm} / 1000 \mathrm{yr}$, turbidite (and debris-flow) accumulation rate of $1.7 \mathrm{~cm} / 1000 \mathrm{yr}$, and turbidite frequency of $0.4 / 10,000 \mathrm{yr}$. The maximum frequency is 0.9 turbidites $/ 10,000$ yr. The lower turbidite series (65.4-75.4 mbsf) is composed of only thin turbidite layers, but the frequency of these 21 turbidite layers is slightly higher than in the upper turbidite series. From an average bulk-sedimentation rate of $3.3 \mathrm{~cm} / 1000 \mathrm{yr}$, the calculated turbidite accumulation rate is $0.5 \mathrm{~cm} / 1000 \mathrm{yr}$, and the frequency average is 0.7 turbidite/ $10,000 \mathrm{yr}$, with a maximum of 1 turbidite $/ 10,000 \mathrm{yr}$.

\section{Hole $632 A$}

At Hole 632A, we recovered a Quaternary turbidite series from Core $101-632 \mathrm{~A}-1 \mathrm{H}$ down to Core 101-632A-6H $(0-50.5$ mbsf). Determination of age based on foraminifers in Sample 101-632A-6H-5, 72-74 cm, yielded a late Pliocene age, and a core-catcher sample from Core 101-632A-6H yielded an early late Pliocene age (Austin, Schlager, et al., 1986). We determined that the average accumulation rate of the Quaternary turbidite

\section{SITE 628 HOLE A}
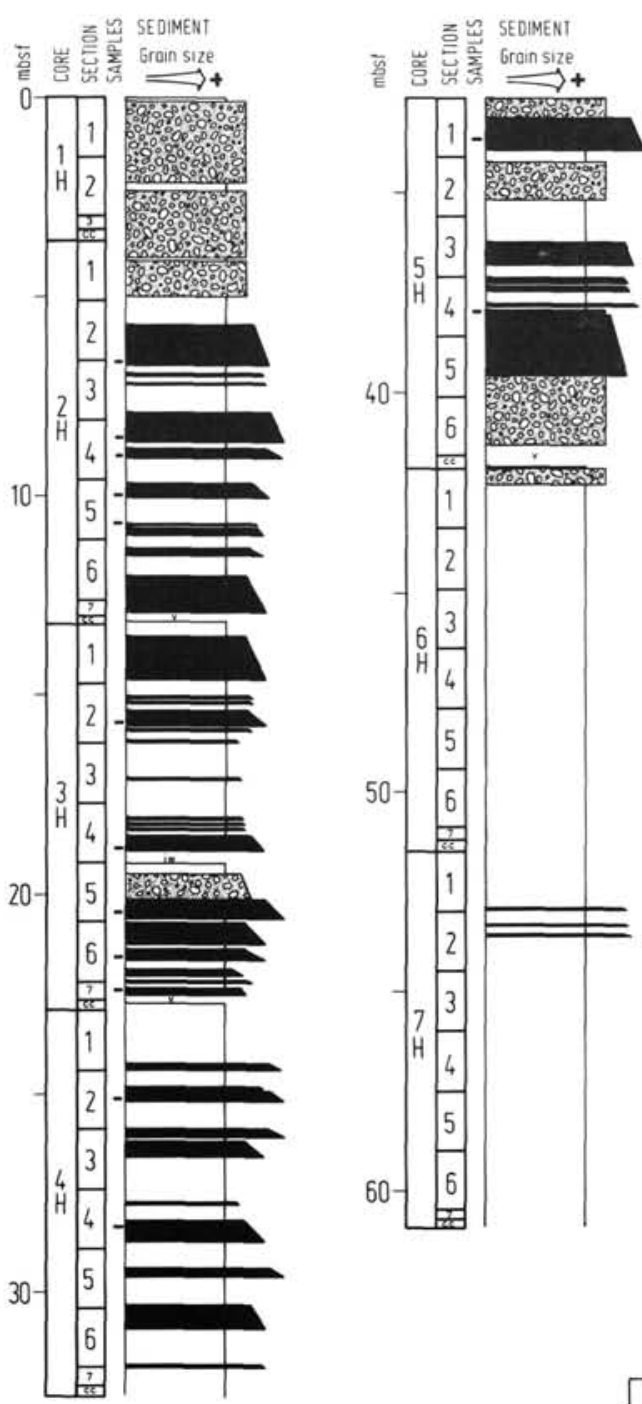

SITE 632
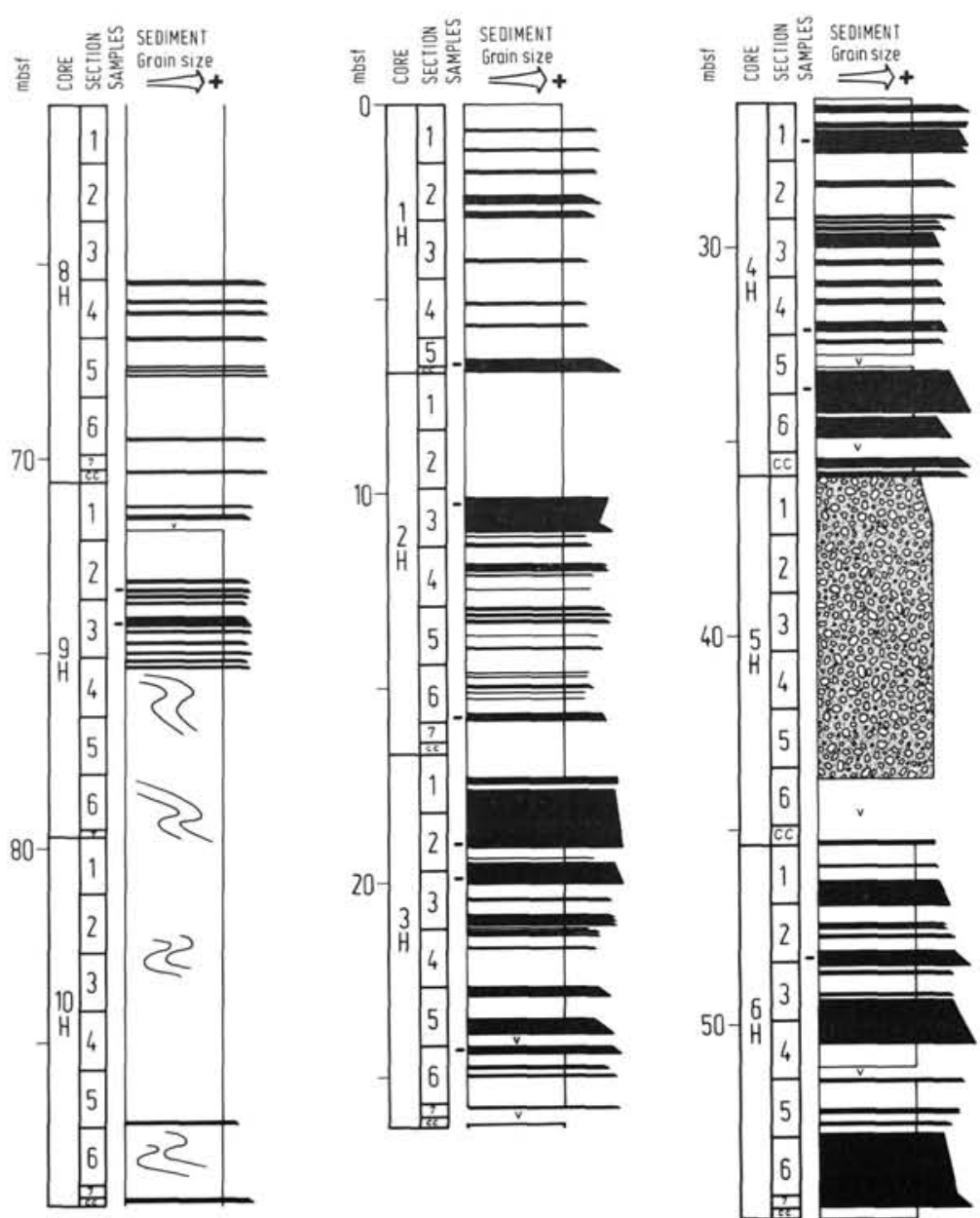

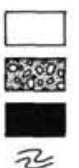

calcareous periplatform ooze unlithified floatstone, packston and rudstone (debris flows) unlithified grainstone (turbidites)

$\checkmark$ void

iw $\begin{aligned} & \text { interstitial water } \\ & \text { sample (void) }\end{aligned}$

slump folds

Figure 3. Lithology of Holes 628A and 632A. In Hole 628A, the turbidite sequence down to Core 101-628A-5H contains some debris-flow sheets (inner base-of-slope carbonate apron). Turbidites are less frequent and thinner in the sediments from Cores 101-628A-6H through 101-628A-10H (outer base-of-slope carbonate apron). Core 101-632A-5H contains sediments that we interpreted either as a thick debris-flow sheet strongly disturbed by drilling or as downhole debris (Austin, Schlager, et al., 1986). 
series was $22 \mathrm{~m} / \mathrm{m} . \mathrm{y}$. (Austin, Schlager, et al., 1986). This rate decreased in the lower part of Core 101-632A-6H (Fig. 2); therefore, we investigated only the turbidite series down to $50.5 \mathrm{mbsf}$ for this study. Core 101-632A-5H contained sediments that we interpreted as downhole debris or as a thick debris-flow sheet disturbed by drilling. Consequently, that core (35.9-45.4 mbsf) was not accounted for in the following calculations.

The turbidite series from 0 to 35.9 mbsf and from 45.4 to 50.5 mbsf consists of 73 turbidite layers ranging from a few to more than $100 \mathrm{~cm}$ thick. These layers are intercalated with calcareous periplatform ooze (Fig. 3). Using an average sedimentation rate of $2.2 \mathrm{~cm} / 1000 \mathrm{yr}$, the turbidite accumulation rate was $0.7 \mathrm{~cm} / 1000 \mathrm{yr}$ with an average turbidite frequency of 0.4 turbidite/ 10,000 yr. Maximum turbidite frequency was 0.9 turbidite/ 10,000 yr.

\section{Texture of the Turbidite Layers}

Most of the turbidite layers have a grainstone to packstone texture. Six layers from 30 sampled turbidites contain more than $10 \%$ gravel in the sampled interval (Table 1). The amount of gravel reaches $48 \%$ in Sample 101-628A-5H-4, 85-87 cm, and the sand content is low at $33 \%$. These turbidite sections have rudstone trending to floatstone textures. In 21 samples the amount of gravel is below $1 \%$, and in three samples it is between $1 \%$ and $10 \%$.

Sand is the main grain-size component in the investigated turbidite samples. Except for Sample 101-628A-5H-4, 85-87 cm, the amount of sand is higher than $50 \%$. On average, samples from Hole $628 \mathrm{~A}$ contain $71 \%$ sand, those from Hole $632 \mathrm{~A}$,
$78 \%$, and in samples from Hole 635A (which was sampled for a comparative study) the sand content is $94 \%$.

Samples from Hole 628A make up the highest silt (up to $29 \%$ ) and clay content (up to $20 \%$ ). Average values are $13 \%$ for silt and $10 \%$ for clay. For samples from Hole $632 \mathrm{~A}$, the average values are $8 \%$ for silt and $8 \%$ for clay. Samples from Hole 635A contain low percentages of both sand and clay (both $3 \%$ on average).

Mean grain size varies from $870 \mu \mathrm{m}(0.2 \phi)$ to $40 \mu \mathrm{m}(4.7 \phi)$. The average value for samples from Hole $628 \mathrm{~A}$ is $120 \mu \mathrm{m}(3.1 \phi)$, while for Holes 632A and 635A, it is $220 \mu \mathrm{m}(2.2 \phi)$ and $350 \mu \mathrm{m}$ $(1.5 \phi)$, respectively. The sediments are moderately to extremely poorly sorted (sorting coefficient is $0.8 \phi$ to $4.2 \phi$ ). Average values for sorting are $2.7 \phi$ for Hole $628 \mathrm{~A}, 2.4 \phi$ for Hole $632 \mathrm{~A}$, and $1.1 \phi$ for Hole $635 \mathrm{~A}$. Usually, the samples have excess fine material and are strongly fine-skewed with average values of +0.4 for Hole $628 \mathrm{~A}$ and +0.5 for Hole $632 \mathrm{~A}$. Only Sample 101-635A-1R-2, $85-87 \mathrm{~cm}$, has a negative skewness $(-0.4)$. Most samples have kurtosis values that usually plot between 1.5 and 3. Nearly all investigated samples show unimodal grain-size distributions.

\section{Composition of the Turbidite Layers}

In the 500-1000- $\mu \mathrm{m}$ sand fraction, little hydraulic differentiation of grains of different shapes or densities seems to have occurred during transportation and deposition because the combinations and percentages of different components vary greatly in the sampled turbidites. The weight percentages of the 500$1000-\mu \mathrm{m}$ grain-size fraction vary from $0.2 \%$ to $67.9 \%$, with an average value of $12.6 \%$.

Table 1. Grain-size composition and grain-size parameters of turbidite samples.

\begin{tabular}{|c|c|c|c|c|c|c|c|c|c|c|}
\hline Sample $(\mathrm{cm})$ & $\begin{array}{l}\text { Depth } \\
\text { (mbsf) }\end{array}$ & $\begin{array}{c}\text { Gravel } \\
(\%)\end{array}$ & $\begin{array}{c}\text { Sand } \\
(\%)\end{array}$ & $\begin{array}{l}\text { Silt } \\
(\%)\end{array}$ & $\begin{array}{l}\text { Clay } \\
(\%)\end{array}$ & $\begin{array}{c}\text { Median } \\
(\phi)\end{array}$ & $\begin{array}{c}\text { Mean } \\
(\phi)\end{array}$ & $\begin{array}{l}\text { Sorting } \\
(\phi)\end{array}$ & Skewness & Kurtosis \\
\hline \multicolumn{11}{|l|}{ Hole 628A } \\
\hline $2 \mathrm{H}-3,2-4$ & 6.63 & 0.5 & 79.2 & 12.7 & 7.6 & 3.0 & 3.4 & 2.1 & +0.4 & 1.9 \\
\hline $2 \mathrm{H}-4,51-53$ & 8.62 & 0.2 & 81.9 & 10.8 & 7.1 & 2.8 & 3.0 & 2.0 & +0.4 & 2.2 \\
\hline $2 \mathrm{H}-4,92-94$ & 9.03 & 0.3 & 82.2 & 6.8 & 10.7 & 1.7 & 2.5 & 2.7 & +0.5 & 1.8 \\
\hline $2 \mathrm{H}-5,40-42$ & 10.01 & 0 & 56.5 & 29.1 & 14.4 & 3.8 & 4.7 & 2.5 & +0.6 & 1.6 \\
\hline $2 \mathrm{H}-5,115-117$ & 10.76 & 0.1 & 78.6 & 12.1 & 9.2 & 2.5 & 2.9 & 2.5 & +0.4 & 1.7 \\
\hline $3 \mathrm{H}-2,93-95$ & 15.64 & 0.1 & 80.2 & 11.4 & 8.3 & 3.1 & 3.5 & 2.0 & +0.4 & 2.9 \\
\hline $3 \mathrm{H}-4,109-111$ & 18.80 & 0.3 & 80.5 & 9.2 & 10.0 & 2.5 & 3.3 & 2.3 & +0.6 & 2.2 \\
\hline $3 \mathrm{H}-5,128-130$ & 20.49 & 0.2 & 84.1 & 9.4 & 6.4 & 3.0 & 2.9 & 1.9 & +0.1 & 2.7 \\
\hline $3 \mathrm{H}-6,95-97$ & 21.66 & 20.5 & 58.6 & 11.6 & 9.3 & 1.9 & 1.9 & 3.9 & +0.1 & 1.7 \\
\hline $3 \mathrm{H}-7,14-16$ & 22.35 & 14.9 & 65.0 & 10.8 & 9.4 & 2.0 & 2.5 & 3.5 & +0.2 & 2.8 \\
\hline $4 \mathrm{H}-2,79-81$ & 25.20 & 0 & 80.7 & 11.8 & 8.0 & 2.0 & 3.0 & 2.4 & +0.7 & 1.9 \\
\hline $4 \mathrm{H}-4,79-81$ & 28.20 & 0.9 & 78.7 & 10.6 & 9.8 & 2.5 & 3.3 & 2.4 & +0.6 & 1.9 \\
\hline $5 \mathrm{H}-1,105-107$ & 33.66 & 3.7 & 73.9 & 13.3 & 9.2 & 2.0 & 2.9 & 2.9 & +0.5 & 1.5 \\
\hline $5 \mathrm{H}-4,85-87$ & 37.96 & 47.7 & 33.3 & 10.5 & 8.5 & -0.7 & 0.6 & 4.2 & +0.5 & 0.9 \\
\hline $9 \mathrm{H}-2,126-128$ & 73.37 & 5.3 & 51.1 & 23.5 & 20.0 & 3.7 & 4.4 & 3.8 & +0.2 & 1.1 \\
\hline $9 \mathrm{H}-3,62-63$ & 74.23 & 0.1 & 74.9 & 15.4 & 9.6 & 3.4 & 4.1 & 2.1 & +0.6 & 2.5 \\
\hline \multicolumn{11}{|l|}{ Hole 632A } \\
\hline $1 \mathrm{H}-5,67-63$ & 6.68 & 28.6 & 52.9 & 9.2 & 9.2 & 0.3 & 1.0 & 4.0 & +0.3 & 1.2 \\
\hline $2 \mathrm{H}-3,38-42$ & 10.30 & 0 & 93.9 & 3.3 & 2.9 & 2.7 & 2.8 & 1.0 & +0.3 & 1.7 \\
\hline $2 \mathrm{H}-6,140-144$ & 15.82 & 18.9 & 71.7 & 4.2 & 5.2 & 0.2 & 0.2 & 2.3 & +0.3 & 2.0 \\
\hline $3 \mathrm{H}-2,86-90$ & 19.08 & 11.4 & 68.9 & 8.9 & 10.9 & 0.4 & 1.8 & 3.4 & +0.6 & 1.5 \\
\hline $3 \mathrm{H}-3,19-23$ & 19.92 & 0.8 & 83.1 & 8.3 & 7.8 & 1.6 & 2.2 & 2.5 & +0.5 & 1.8 \\
\hline $3 \mathrm{H}-6,9-12$ & 24.30 & 0 & 84.5 & 8.0 & 7.4 & 2.4 & 2.7 & 1.8 & +0.6 & 2.6 \\
\hline $4 \mathrm{H}-1,100-102$ & 27.31 & 3.0 & 79.5 & 8.7 & 8.8 & 1.7 & 2.3 & 1.4 & +0.5 & 1.8 \\
\hline $4 \mathrm{H}-4,133-135$ & 32.14 & 0.3 & 81.7 & 10.4 & 7.6 & 2.5 & 3.0 & 2.1 & +0.5 & 2.1 \\
\hline $4 \mathrm{H}-5,140-142$ & 33.71 & 0.6 & 78.6 & 10.2 & 10.6 & 2.6 & 3.3 & 2.5 & +0.5 & 2.2 \\
\hline $6 \mathrm{H}-2,140-142$ & 48.31 & 0 & 81.1 & 8.5 & 10.4 & 1.4 & 2.4 & 2.8 & +0.6 & 1.9 \\
\hline \multicolumn{11}{|l|}{ Hole 635A } \\
\hline $1 \mathrm{R}-1,57-59$ & 0.58 & 0 & 94.4 & 4.1 & 1.5 & 1.8 & 1.9 & 1.0 & +0.4 & 1.6 \\
\hline $1 \mathrm{R}-1,109-111$ & 1.10 & 0 & 89.8 & 5.4 & 4.8 & 2.4 & 2.6 & 1.7 & +0.5 & 2.0 \\
\hline $1 \mathrm{R}-2,56-58$ & 2.07 & 0.2 & 95.7 & 1.9 & 2.3 & 0.6 & 0.7 & 0.8 & +0.3 & 1.8 \\
\hline $1 \mathrm{R}-2,85-87$ & 2.36 & 0.6 & 96.0 & 1.6 & 1.8 & 1.2 & 0.9 & 0.9 & -0.4 & 0.8 \\
\hline
\end{tabular}




\section{Hole 628A}

Planktonic components predominate in the $500-1000-\mu \mathrm{m}$ fraction of the turbidite samples from Hole 628A (Table 2). Planktonic foraminifers of the genera Globigerina and Orbulina are common and often are found cemented into small aggregates. In the sediment sequence downhole of Sample 101-628A$3 \mathrm{H}-2$, 93-95 cm (15.64 mbsf), Orbulina is less common than Globigerina and other planktonic foraminifers (Globorotaliidae). In the lower investigated part of Hole $628 \mathrm{~A}$, Orbulina tests are common. A large amount of pteropod shells occurs in the upper part of the turbidite sequence downhole of Sample 101-628A-3H-5, 128-130 cm (20.49 mbsf). Samples below this depth contain no pteropod shells within the $500-1000-\mu \mathrm{m}$ fraction. Gastropod shell fragments and Halimeda fragments show a similar trend and do not occur below this depth.

Fragments of benthic-organism skeletons are rare in the 500$1000-\mu \mathrm{m}$ fraction of the samples investigated from Hole 628A. Skeletons of organisms living in shallow waters of the carbonate platform or on the upper slope, such as foraminifers of the family Soritidae, Homotrema rubrum, or Halimeda spp., also are rare. No ooids were found in samples from this hole. Grain aggregates are abundant below Sample 101-628A-5H-1, 105-107 cm.

Samples 101-628A-9H-2, 126-128 cm, and 101-628A-9H-3, $62-63 \mathrm{~cm}$, contain generally only one component-grain aggregates having a chalky, micritic cement (individual grains not counted). Unidentified fine sand grains are cemented into small aggregates in Sample 101-628A-9H-2, 126-128 cm. In Sample 101-628A-9H-2, 62-63 cm, most of the cemented sand grains are planktonic foraminifers.

The ratio of all benthic to all planktonic components shows that planktonic components predominate (Fig. 3). Downhole variation is low, although a small decrease of planktonic components occurs in relation to benthic material at about 20 mbsf. Only Sample 101-628A-2H-4, 92-94 cm (9.03 mbsf), shows a strong increase of benthic components. The same downhole trend is seen in a plot of benthic vs. planktonic foraminifers (Fig. 4).

\section{Hole $632 A$}

A large amount of skeletal fragments from benthic organisms is seen in samples from Hole 632A. Skeletal fragments from Halimeda, red algae, and planktonic-foraminifer tests are the main components. Other common components include skeletal fragments from benthic organisms, grains derived from echinoids, bryozoans, corals, ostracodes, worm tubes, and some unidentified polished grains (Table 2).

Common benthic components are Soritidae, Homotrema rubrum, and Halimeda fragments, which are produced in shallowplatform or upper-slope environments. Ooids are found only in Sample 101-632A-2H-3, 38-42 cm (less than 0.5\%).

Planktonic components are more common below Sample 101632A-4H-4, 133-135 cm (32.14 mbsf), which contains abundant pteropod shells. Sample 101-632A-4H-5, 140-142 cm (33.71 mbsf), and Sample 101-632A-6H-2, 140-142 cm (48.31 mbsf), have higher percentages of planktonic foraminifers. The lowermost investigated sample (Sample 101-632A-6H-2, 140-142 cm) contains almost no pteropod shells, no tests of Soritidae or $\mathrm{Ho}$ motrema rubrum, and no gastropod or bivalve shells. Instead, the amount of aggregates is correspondingly large (Table 2).

Benthic components are more common than planktonic components downhole to approximately $30 \mathrm{mbsf}$. A maximum value of benthic vs. planktonic components is reached at around 20 mbsf. More planktonic than benthic components occur in the $500-1000-\mu \mathrm{m}$ grain-size fraction of the investigated turbidite samples below Sample 101-632A-4H-4, 133-135 cm (32.14 mbsf). The ratio of benthic vs. planktonic foraminifers shows the same trend downhole as the ratio of benthic vs. planktonic components (Fig. 4).

\section{DISCUSSION}

\section{Frequency of Turbidites and Sea-Level Fluctuations}

The average turbidite frequency of 0.7 turbidites $/ 100,000 \mathrm{yr}$ is far too low to recognize variations related to major sea-level fluctuations, the periodicities of which are on the order of 20,000 to 100,000 yr. Turbidite frequency is nearly 10 times lower than in the turbidite sequences in the southern Tongue of the Ocean, i.e., the area investigated by Droxler and Schlager (1985). However, further studies of oxygen-isotope ratios or cyclic variations in the calcite and aragonite contents of the intercalated periplatform ooze may reveal sea-level phases (Droxler, 1984; Droxler and Schlager, 1985; Droxler et al., this volume). With this information, small differences in turbidite frequency or turbidite accumulation rate during high and low sea-level stands may become apparent, even in Holes 628A and 632A.

\section{Turbidite Composition and Depositional Environments}

\section{Texture}

The texture of turbidite layers is influenced by (1) the source material, (2) erosion and sorting processes during transportation and deposition, and (3) diagenetic changes after deposition. In addition, measured values are largely determined by inadequate sampling of inhomogeneous turbidites (graded bedding) and by a small sample volume and number. The measured grain-size distributions and the calculated grain-size parameters (Tables 1 and 2) therefore are not representative of certain turbidite layers.

However, some differences in the textures of the turbidites from Holes 628A, 632A, and 635A exist and may characterize the specific depositional environment. The Pliocene sediment sequence from Site 628 on the northern slope of Little Bahama Bank contains some mud-supported conglomeratic debris-flow sheets and turbidites that are more poorly sorted and have larger amounts of silt and clay than the turbidites from Sites 632 and 635. This is characteristic of carbonate-slope facies having deposits of proximal, low-energy turbidity currents and muddy debris flows. In this environment, turbidity currents are not channeled into only a few deeply eroded, nearly stationary canyons, but flow down many gullies, which may change their strike frequently. In an environment without a prepared and washed-out thalweg, turbidity currents may erode a large amount of predeposited periplatform ooze and redeposit it during the waning stage of flow after a short transportation distance. This is corroborated by the occurrence of small, muddy, unlithified clasts at the base of the turbidites and by the small mean grain sizes.

The Quaternary and Pliocene sediment sequence at Site 628 can be described in terms of a base-of-slope carbonate apron model (Mullins and Cook, 1986). The sediments show a facies transition from an outer apron facies in the lower part (Cores $101-628 \mathrm{~A}-6 \mathrm{H}$ through $101-628 \mathrm{~A}-10 \mathrm{H}$ ) characterized by only a few, thin turbidites to an inner apron facies characterized by numerous, coarse-grained, thick turbidites and mud-supported debris-flow sheets in the upper five cores. This probably reflects a Neogene seaward progradation of the northern slope of Little Bahama Bank (Austin, Schlager, et al., 1986).

At Site 633, turbidites are not common in a toe-of-slope environment analogous to that of Site 628 . Sediments from the most basinward site in Exuma Sound (Site 632) contain the highest amount of turbidites. Mud-supported, debris-flow sheets do not occur. The investigated samples show better sorting, a smaller mud content, and higher mean grain sizes than the samples from Hole 628A. We propose that the turbidites in the Quaternary sediment section from Hole 632A were deposited after longer transportation, either from the adjacent platform slopes or from northern Exuma Sound, because Site 632 is situated in the mid- 
Table 2. Components of the 500-1000- $\mu \mathrm{m}$ grain-size fraction of turbidite samples from different depositional environments.

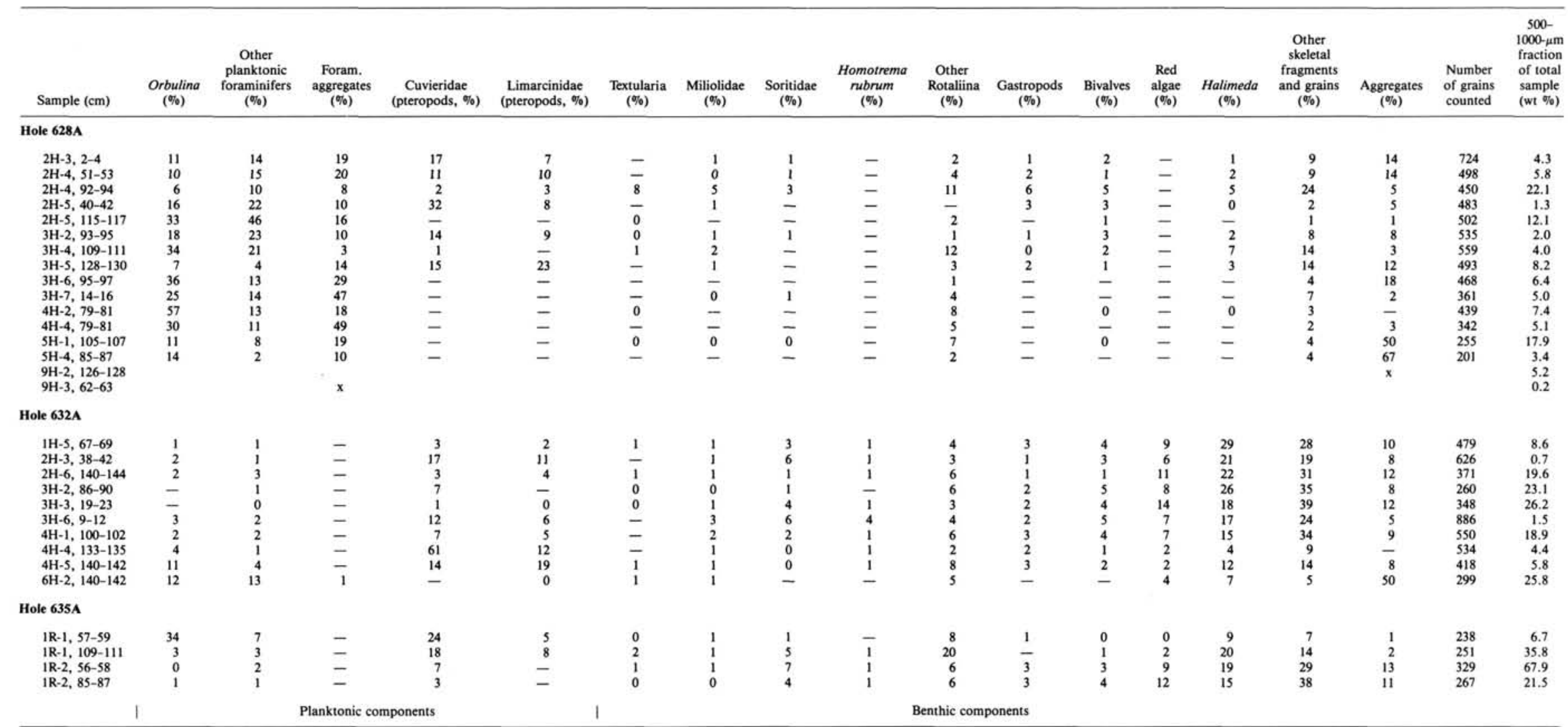

Note: Values were rounded off to whole percentages; $0=0.01-0.49 \% ;-=$ component not counted; $\mathrm{x}=$ estimated main component more than $90 \%$. 

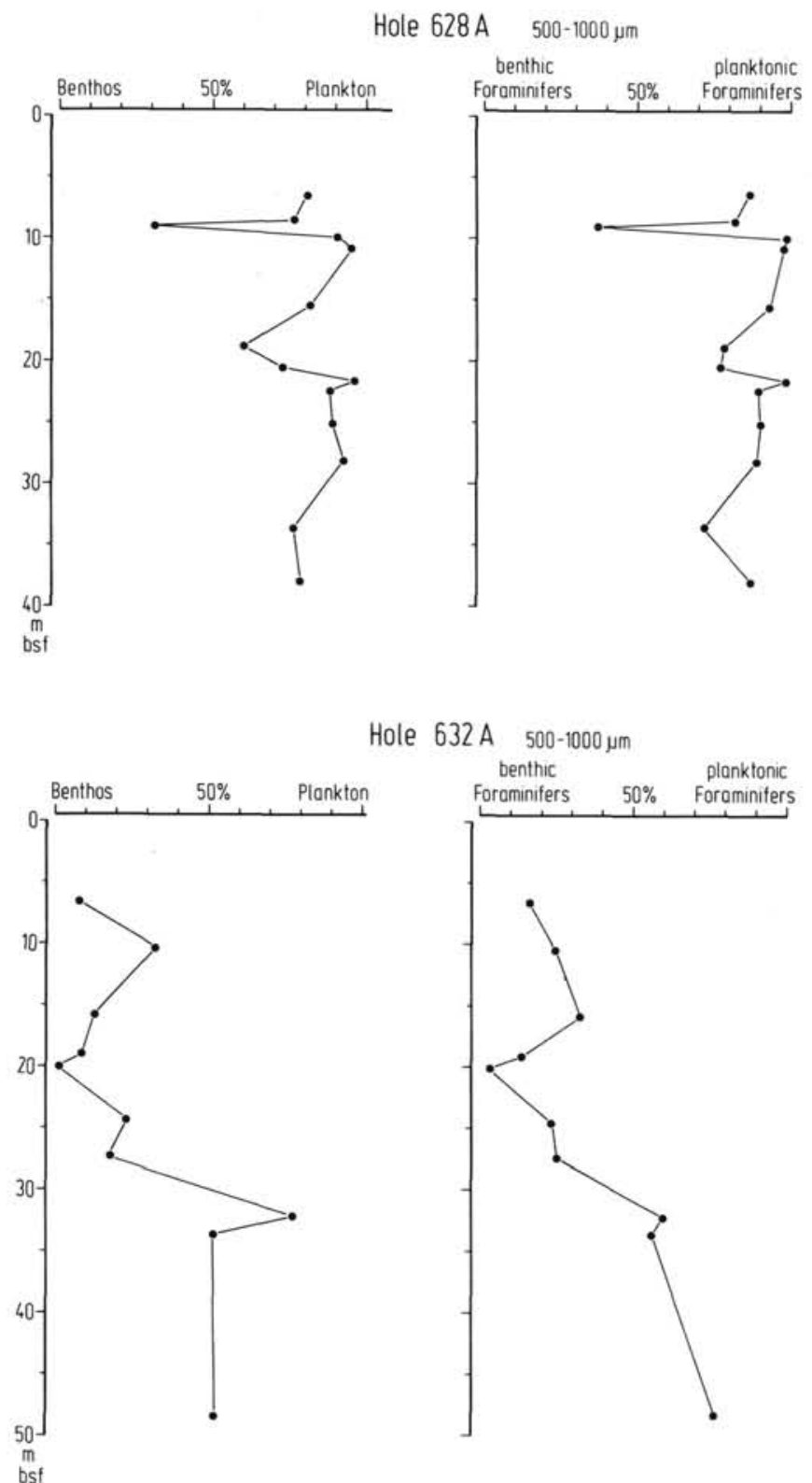

Figure 4. Variations of the proportion of all benthic and planktonic components (left side) and of benthic and planktonic foraminifers (right side) in the 500-1000- $\mu \mathrm{m}$ fraction from turbidite samples; Holes $628 \mathrm{~A}$ and $632 \mathrm{~A}$.

dle of the thalweg for turbidity currents from the entire reentrant (Austin, Schlager, et al., 1986).

Site 635, in the thalweg of Northeast Providence Channel, is situated in a comparable environment. We recovered canyon-fill sediments in Hole 635A (Austin, Schlager, et al., 1986). Samples from those turbidites have good grain-size sorting as sand content is more than $90 \%$. This may reflect the long transportation from either Northwest Providence Channel or from the enclosed basin of the Tongue of the Ocean.

\section{Composition of the 500-1000- $\mu$ m Grain-size Fraction}

Composition of the turbidites may be controlled by (1) the composition of the source material; (2) sorting owing to different grain size, shape, density, and resistance during transportation and deposition; and (3) selective solution during early dia- genesis. We tried to study the changes in composition from different sources by investigating only the $500-1000-\mu \mathrm{m}$ grain-size fraction, which contains both planktonic and benthic components in varying amounts. We assumed that the effect of different sorting processes on the composition of the narrow 500$1000-\mu \mathrm{m}$ grain-size fraction was minimal.

Compositional changes from selective solution may have occurred in sediments from Hole 628A below Section 101-628A$3 \mathrm{H}-6$ because no pteropod shells and no Halimeda fragments (both aragonite) were found in the 500-1000- $\mu \mathrm{m}$ fraction (Table 2). This may indicate incipient solution and decomposition of aragonitic grains. It is also possible that aragonite grains were more easily broken during sample preparation and sieving. X-ray diffractometry showed that aragonite still occurs in any grain-size fraction smaller than $63 \mu \mathrm{m}$. Shipboard X-ray diffractometry studies also revealed a decrease of aragonite content in sediments below 20 mbsf (Austin, Schlager, et al., 1986). The large amount of aggregates in samples from Cores 101-628A-5H, 101-628A-9H, and 101-632A-6H also may result from early diagenetic lithification.

Turbidites from Holes 628A and 632A differ considerably because of different source areas. Planktonic components, such as the tests of planktonic foraminifers and pteropod shells, dominate in the investigated turbidite material from Hole $628 \mathrm{~A}$ (Fig. 5). We suggest that most of this sediment was eroded and picked up on the northern slope of Little Bahama Bank by turbidity currents during their downslope flow. Frequent changes in the flow-off system caused by the absence of deeply eroded channels and frequent, small, local turbidity currents along the whole slope may result in the erosion and entrainment of slope sediment containing large amounts of skeletons from planktonic organisms. Tests of foraminifers of the family Soritidae and Homotrema rubrum or Halimeda fragments (Fig. 5) indicate a small amount of platform material in the sediments. Thus, we concluded that little downslope transportation of platform material by turbidity currents occurs on the northern slope of Little Bahama Bank. Only Sample 101-628A-2H-4, 92-94 cm, contains a large amount of benthic and platform material, which indicates a platform-derived source. The platform material possibly is diluted by large amounts of planktonic material on this low-angle slope of the Little Bahama Bank. Less planktonic material has accumulated on the steeper slope of the Exuma Sound.

In contrast, turbidites having large amounts of platform material were found at Site 632 (Fig. 5). Skeletal parts from benthic organisms that may live in different water depths, such as red algae, gastropods, bivalves, echinoids, bryozoans, ostracodes, worm tubes, and foraminifers of the suborder Textulariina, family Miliolidae, and suborder Rotaliina, are common. Also common are components derived from upper-slope or platform environments, such as Halimeda fragments, foraminifers of the family Soritidae, Homotrema rubrum, coral or Millepora fragments, as well as unidentified polished grains (Table 2; Fig. 5). Ooids are rare in the investigated material. The enclosed, platform-surrounded setting of Exuma Sound is an important factor for the large amount of benthic and platform material in the investigated turbidites.

Turbidity currents may develop across the surrounding platform margins, which are probably unstable owing to steeper slopes and reach the floor of Exuma Sound from different directions. The steep slopes do not provide a large area for sedimentation of planktonic components. In the central axis of Exuma Sound, where the turbidity currents are channeled, the area of sediment containing larger amounts of planktonic material available for erosion is further reduced. Other factors resulting in a smaller amount of planktonic material are (1) the large platform area compared with the low slope width (i.e., a small 
A
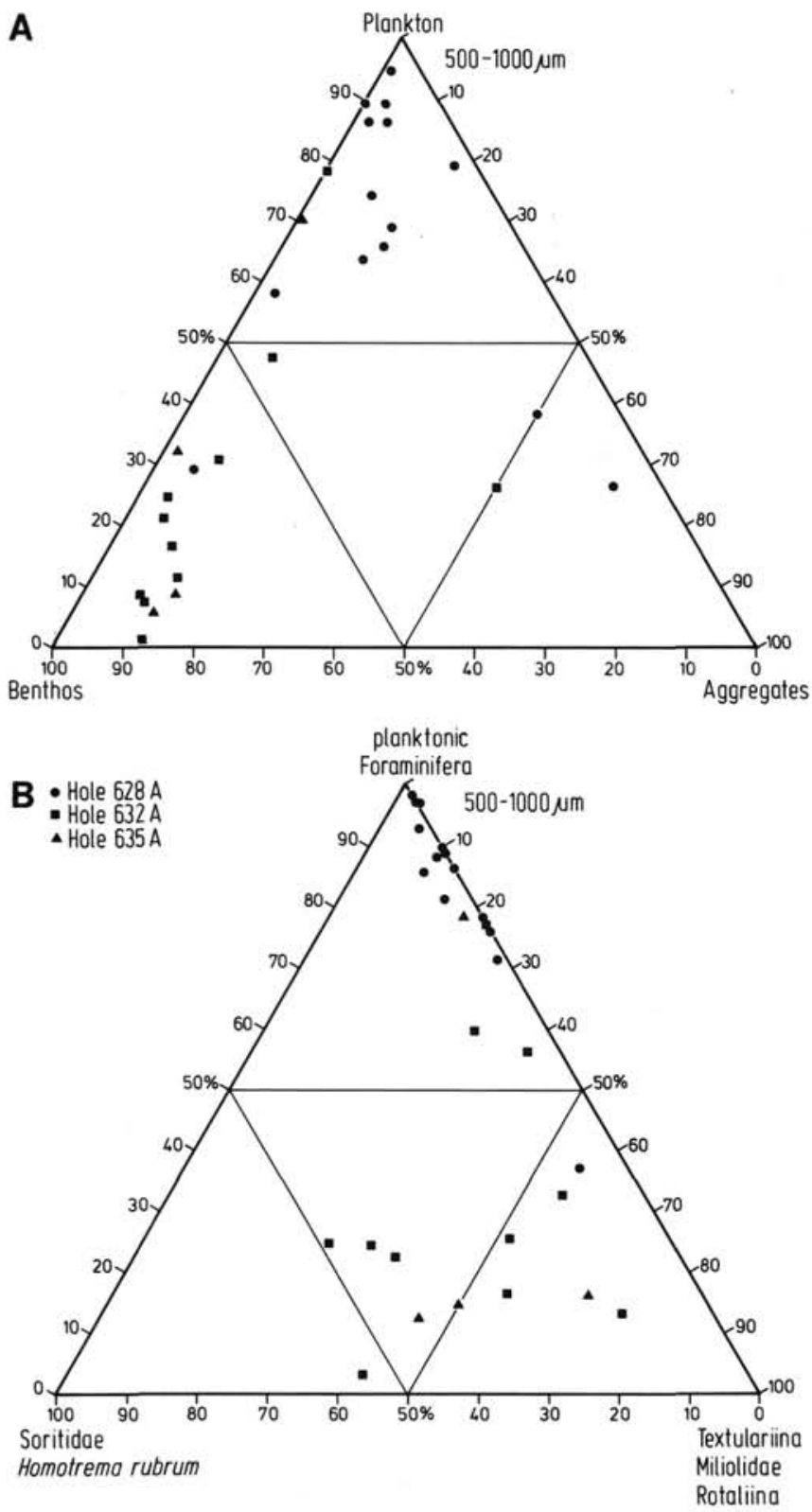

Figure 5. A. Proportion of planktonic components, benthic components, and aggregates in turbidite samples (500-1000- $\mu \mathrm{m}$ fraction) from Holes $628 \mathrm{~A}, 632 \mathrm{~A}$, and 635A. B. Proportion of planktonic foraminifers, benthic foraminifers (Textulariina, Miliolidae, and Rotaliina), and shallowwater benthic foraminifers (Soritidae, Homotrema rubrum) in turbidite samples (500-1000- $\mu \mathrm{m}$ fraction) from Holes $628 \mathrm{~A}, 632 \mathrm{~A}$, and $635 \mathrm{~A}$ Samples from Hole 628A plot in the corner of planktonic components $(A)$ and planktonic foraminifers $(B)$. Samples from Holes 632A and 635A plot in the corner of benthic components $(A)$ and benthic foraminifers $(B)$; they also contain higher proportions of shallow-water foraminifers.

source area of plankton and dilution by platform benthic organisms) and (2) the channeling and bypassing of the slope by turbidity currents (Austin, Schlager, et al., 1986).

Since the preferred habitat of planktonic, pelagic organisms is open-ocean water, one expects that the productivity of these organisms and their supply to the sediments are not optimal in the enclosed water masses of Exuma Sound. The uphole decrease in planktonic components in Hole 632A (Fig. 4) suggests a change in this environment. In the late Pliocene and earliest Quaternary, Exuma Sound possibly was more open to the Atlantic than it is today. The passages (perhaps between Cat Is- land and Eleuthera) could later have been closed by rapid progradation of the platform in the Quaternary.

At Site 635 in the Northeast Providence Channel, a few samples were recovered for comparative studies. The composition of three out of the four samples is similar to samples from Site 632 (Fig. 5). Perhaps the material of these turbidites comes from the enclosed basin of Tongue of the Ocean. Sample 101-635A-1R-1, $57-59 \mathrm{~cm}$, however, contains a high amount of planktonic components. We interpreted this as material from an open-ocean platform slope that may be derived from the Northwest Providence Channel, a broad channel open on both sides to ocean waters. Turbidity currents may develop along the southern slopes of Little Bahama Bank and along the northern slopes of Great Bahama Bank. Also, turbidity currents from the Straits of Florida possibly may flow toward and down Northwest Providence Channel.

\section{SUMMARY}

A Pliocene turbidite sequence from Site 628 , on the northern slope of Little Bahama Bank, was examined and compared with a similar Quaternary sequence from Site 632, in the center of southeast Exuma Sound. At both sites sediment-accumulation rates and turbidite frequencies were too low to correlate them with Quaternary or Pliocene glacial/interglacial sea-level fluctuations. However, textures of gravity-flow sheets do allow differentiation between sedimentation in an open-ocean, accretionary base-of-slope carbonate apron at Site 628 and in a basin enclosed by steep slopes bypassed by turbidity currents at Site 632 .

Mud-supported debris flows and turbidites having high mud content and poor sorting are typical of the sediment sequence at the base of the northern slope of Little Bahama Bank. Gravity flows may occur along the whole slope, flowing downslope in a regional canyon system that is less pronounced than on a steeper slope and that may change with time. Therefore, the gravity flows erode and entrain large amounts of fine-grained slope sediment. The proximal gravity-flow sheets at Site 628 were deposited by small, low-energy, local gravity flows.

At Site 632, no mud-supported debris flows occur. Mean grain size of the turbidite samples is larger, mud content is lower, and the sorting coefficient is better than in samples from Hole 628A. This reflects the basin-axis setting of Site 632, through which all larger, high-energy turbidity currents from the slope of Exuma Sound must pass on their way to the sea. This long transportation path is reflected by better sorting of the deposited material. We also noticed this in the good sorting of some turbidite samples from Site 635, in the central axis of Northeast Providence Channel.

Composition of the 500-1000- $\mu \mathrm{m}$ grain-size fraction of the investigated turbidite samples provided information about their source. Turbidites from Site 628 contain a large amount of planktonic components, while platform detritus is rare. This may result from a large amount of eroded and reworked slope sediment transported only a short distance by turbidity currents or low-energy gravity flows. In contrast, turbidites at Site 632 contain large amounts of skeletal fragments from benthic organisms that lived on the carbonate platforms surrounding Exuma Sound. The small amount of planktonic components may be interpreted as the result of (1) large platform areas compared with the small slope and basin areas where planktonic components normally would be deposited (i.e., small source area of plankton and dilution by platform benthic organisms), (2) the small amount of slope sediment eroded and picked up by the turbidity currents owing to bypassing of the steep Exuma Sound slopes by these currents, and (3) a lower production of pelagic, planktonic components in the enclosed water masses of Exuma Sound.

Platform progradation is indicated by a facies transition from an outer- to an inner-debris apron in the upper sediment se- 
quence of Hole 628A and by the decrease uphole of planktonic components (no evidence for diagenetic changes) in Hole 632A.

Turbidite material derived from both open-ocean and enclosed-basin environments was found at Site 635, in the Northeast Providence Channel. Composition of three out of four samples indicates an enclosed basin as the source area. Perhaps these turbidity currents came from the Tongue of the Ocean. One sample contains large amounts of planktonic components and is interpreted as material from the slopes of Northwest Providence Channel, which is far more open to ocean waters.

\section{ACKNOWLEDGMENTS}

We express our appreciation to the Alfred Wegener Institute for Polar and Marine Research (Bremerhaven) for providing us with the opportunity to conduct most of this study. We thank James A. Austin, Jr., Dieter Fütterer, Roland Goldring, Amanda A. Palmer, Andreas Mackensen, Wolfgang Schlager, Bruce H. Wilkinson, and especially Frances Westall (who also vetted the first draft of the manuscript linguistically) for reviewing the manuscript.

We also thank the Deutsche Forschungsgemeinschaft (Project No. Me 267/26-1) for its support.

This is Contribution No. 44 of the Alfred Wegener Institute for Polar and Marine Research, Bremerhaven, Federal Republic of Germany.

\section{REFERENCES}

Austin, J. A., Jr., Schlager, W., et al., 1986. Proc. ODP, Init. Repts. (Pt. A), 101: College Station, TX (Ocean Drilling Program).

Boardman, M. R., and Neumann, A. C., 1984. Sources of periplatform carbonates: Northwest Providence Channel, Bahamas. J. Sediment. Petrol., 54:1110-1123.

Bouma, A. H., 1962. Sedimentology of Some Flysch Deposits. A Graphic Approach to Facies Interpretation: Amsterdam (Elsevier).

1972. Recent and ancient turbidites and contourites. Gulf Coast Assoc. Geol. Soc. Trans., 22:205-221.

Crevello, P. O., and Schlager, W., 1980. Carbonate debris sheets and turbidites, Exuma Sound, Bahamas. J. Sediment. Petrol., 50:11211148.
Droxler, A. W., 1984. Late Quaternary glacial cycles in the Bahamian deep basins and in the adjacent Atlantic Ocean [Ph.D. dissert.]. Univ. Miami.

Droxler, A. W., and Schlager, W., 1985. Glacial versus interglacial sedimentation rates and turbidite frequency in the Bahamas. Geology, 13:799-802.

Folk, R. L., and Ward, W. C., 1957. Brazos River bar: a study in the significance of grain-size parameters. J. Sediment. Petrol., 27:3-26.

Kier, J. S., and Pilkey, O. H., 1971. The influence of sea-level changes on sediment carbonate mineralogy, Tongue of the Ocean, Bahamas. Mar. Geol., 11:189-200.

Lynts, G. W., Judd, J. B., and Stehman, C. F., 1973. Late Pleistocene history of the Tongue of the Ocean, Bahamas. Geol. Soc. Am. Bull., 84:2665-2684.

Meischner, K. D., 1962. Rhenaer Kalk und Posidonienkalk im Kulm des nordöstlichen Rheinischen Schiefergebirges und der Kohlenkalk von Schreufa (Eder). Abh. Hess. Landesamtes Bodenforsch., 39:1-47. 1964. Allodapische Kalke, Turbidite in riff-nahen Sedimentations-Becken. Dev. Sedimentol., 3:156-197.

Mullins, H. T., 1983. Eustatic control of turbidites and winnowed turbidites: Comment. Geology, 11:57-60.

Mullins, H. T., and Cook, H. E., 1986. Carbonate apron models: alternatives to the submarine fan model for paleoenvironmental analysis and hydrocarbon exploration. Sediment. Geol., 48:37-79.

Mullins, H. T., Heath, K. C., vanBuren, H. M., and Newton, C. R., 1984. Anatomy of a modern open-ocean carbonate slope: northern Little Bahama Bank. Sedimentology, 31:141-176.

Shanmugam, G., and Moiola, R. J., 1984. Eustatic control of calciclastic turbidites. Mar. Geol., 56:273-278.

Schlager, W., and Ginsburg, R. N., 1981. Bahama carbonate platformthe deep and the past. Mar. Geol., 44:1-24.

van der Plas, L., and Tobi, A. C., 1965. A chart for judging the reliability of point counting results. Am. J. Sci., 263:87-90.

Date of initial receipt: 5 January 1987

Date of acceptance: 24 June 1987

Ms 101B-147 